\title{
Sport, eksport og selvstændighedskamp
}

Af Rune Ryelund Mortensen

Den 30. juni 2001 spillede Grønland og Tibet en uofficiel landskamp på Vanløse Stadion. Kampen fik stor opmærksomhed i medierne og igangsatte en intens debat og diplomatisk aktivitet, fordi den pustede ild i den gamle konflikt mellem Tibet og Kina. Konflikten om Tibets geopolitiske og folkeretslige status. Arrangementet var indhyllet i en pro-tibetansk retorik, hvilket fik Kina til at indgive protester til Udenrigsministeriet og Grønlands Hjemmestyre. Kineserne påpegede, at Tibet er en del af Kina og ikke en selvstændig nation. Derfor kunne der ikke være tale om en officiel landskamp i regi af FIFA, fordi FIFA kun godkender medlemmer (nationale forbund) fra lande anerkendt af FN og desuden kun anerkender ét forbund i hvert land.

Kinesernes henvendelser til de danske og grønlandske myndigheder medførte kraftige reaktioner og bekymringer i Grønland, fordi man frygtede at vække kinesernes vrede og dermed risikere at miste en betydningsfuld rejeeksport til Kina. Kineserne forsøgte på daværende tidspunkt på at få OL 2008 til Beijing og var derfor i en situation, hvor fokus på kombinationen af sport, politik og menneskerettigheder ville være meget upassende. Dermed var scenen sat for en fodboldkamp, der handlede mest om rejer, uafhængighed og international idrætspolitik - og ikke så meget om fodbold.

I analysen af forspillet til kampen arbej- der jeg ud fra en grundlæggende antagelse om, at sport, i et eller andet omfang, altid er politisk og handler om mere end teknisk og kropslig udfoldelse. Igennem denne optik er de forskellige aktører i udgangspunktet politiske aktører. Derfor er det ikke mit mål at anklage nogen eller finde ud af, om aktørerne sammenblander sport og politik, men at tydeligg øre og dokumentere, hvordan de forskellige aktører brugte kampen til at fremme kulturelle, politiske og kommercielle interesser. Artiklen tilbyder således et eksempel på, hvordan en sportsbegivenhed bruges som redskab i forfølgelsen af politiske interesser.

Artiklen bygger på de skrevne mediers dækning af sagen, personlige interviews med centrale aktører og dokumenter fremskaffet via aktindsigt i Udenrigsministeriets arkiver. Det har ikke været muligt at få adgang til alle dokumenter i ministeriets arkiver. Ministeriet har undtaget syv dokumenter fra aktindsigt med hjemmel i offentlighedslovens $\$ 7$ om korrespondance mellem udenrigsministeriet og dets repræsentationer og ministeriets interne korrespondance, og $\S 13$ stk. 1 , nr. 2 om beskyttelse af væsentlige hensyn til rigets udenrigspolitiske eller udenrigs $\varnothing$ konomiske interesser. ${ }^{1}$ Derudover bygger artiklen på dokumenter og udtalelser fra Grønlands Hjemmestyre (GH) og landsstyreformanden, Tibetan National Football Association (TNFA), Grønlands Idrætsforbund (GIF), 


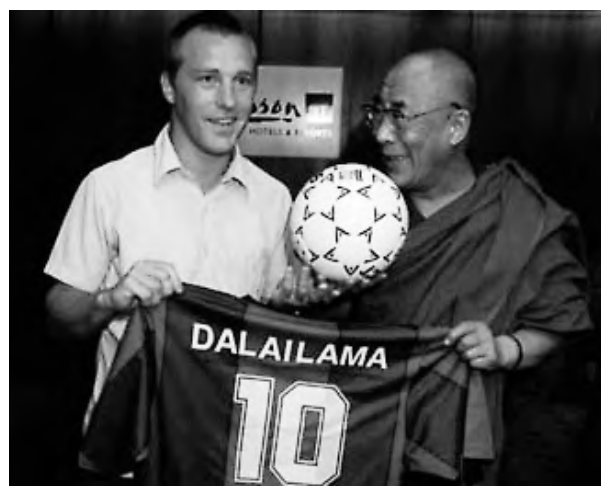

Grønlands Boldspil Union (GBU), Dansk Boldspil Union (DBU), Københavns Idrætsanlæg (KI), Den Kinesiske Ambassade (DKA), Team Grønland (TG) og Den Grønlandske Havfiskeri og Eksport Sammenslutning (APK).

\section{Tibetan National Football Association}

Historien begynder med etableringen af det tibetanske fodboldforbund: TNFA, som var en del af danskeren Michael Nybrandts afgangsprojekt på Kaospilotuddannelsen. Engagementet i tibetansk fodbold udsprang af Nybrandts oplevelse af tibetanernes problemer med at opretholde en national og kulturel identitet. Nybrandt tog til Indien og Nepal for at oprette »et tibetansk fodboldforbund og landshold i flygtningelejrene for det forfulgte folk«, med den begrundelse, at »Boldspillerne $i$ selve Tibet kan ikke få lov af de kinesiske besattere til at danne deres eget landshold «. ${ }^{2}$ Betegnelserne 'det forfulgte folk' og 'de kinesiske besættere' er et udtryk for en pro-tibetansk retorik og altså en klar positionering i Kina-Tibet konflikten. Etableringen af TNFA legitimeredes altså udfra et nationalpolitisk rationale, hvilket tydeliggjorde sammenvævningen af TNFA, nationalistiske og
Michael Nybrandt og Dalai Lama i Københavns Lufthavn (foto: Venligst udlaint af Michael Nybrandt). kulturelle ambitioner. Dette kom med stor symbolsk slagkraft til udtryk, da Nybrandt overrakte Dalai Lama en prototype på den tibetanske spillertrøje i Københavns Lufthavn foran en stor skare af danske og udenlandske journalister.

Ideen om en »landskamp « kom tidligt på banen, fordi Nybrandt anså det for nødvendigt for TNFAs legitimitet. ${ }^{3}$ Han rettede henvendelse til Grønlands Idrætsforbund, fordi deres situation havde en del lighedspunkter med TNFA, og fordi kampen kunne bruges af begge parter til at sætte fokus på deres idrætslige og politiske ambitioner: »Grønland og Tibet er to små nationer, der kamper for deres overlevelse. Under det hele ligger der en masse politiske undertoner «. ${ }^{4}$ Nybrandt tog kontakt til den grønlandske landstræner, Sepp Piontek, som straks var med på ideen og sagtens kunne se provokationen og mulighederne i projektet. ${ }^{5}$ Nybrandt blev sat i forbindelse med GIFs konsulent Jens Brinch, som stod for koordineringen med TNFA.

Den tibetanske selvstændighedskamp udgjorde altså selve idégrundlaget og det ideologiske udgangspunkt for TNFA og fodboldkampen mod Grønland, og kampen blev set som en mulighed for at fremprovokere reaktioner, der kunne sætte fokus på det tibetanske projekt. 


\section{Grфnlands Idratsforbund}

En central tematik i grønlandsk idrætspolitik var på det tidspunkt, og er stadig, afhængigheden af Danmark. Forbundet så fodboldkampen som en mulighed for at markere Grønland som selvstændig nation i en international sammenhæng. ${ }^{6} \mathrm{Da}$ forhandlingerne om afviklingen af Tibet-kampen begyndte i foråret 2000, havde GIF, GBU og DBU allerede $i$ et par år forinden forhandlet med FIFA og UEFA om GBUs optagelse. Forhandlingerne førte ikke til GBUs optagelse - ikke på baggrund af modvilje fra DBU - men pga. af en række tekniske optagelseskrav i forhold til deltagelse i mesterskaber, stadionfaciliteter m.m., som GIF ikke kunne imødekomme. Da forhandlingerne med FIFA og UEFA strandede, begyndte man i Grønland at se sig om efter andre muligheder for at vise det grønlandske flag i internationale sammenhænge. ${ }^{7}$ Således så GIF - på linje med TNFA - et stort potentiale i kampen. GIF kunne ved at deltage i det kontroversielle arrangement sætte fokus på de begrænsede muligheder for deltagelse $\mathrm{i}$ international fodbold og i $\varnothing$ vrigt promovere GIF og GBU som handlekraftige og uafhængige organisationer, i stand til at gøre hvad de ville uden indblanding fra FIFA, UEFA og DBU. Man så det også som en oplagt mulighed for at bidrage til det generelle grønlandske selvstændigg ørelsesprojekt. ${ }^{8}$

\section{Udenrigskontoret $i$ Hjemmestyret}

Den 3. april 2001 sendte GIF et brev til Udenrigskontoret i Hjemmestyret for at orientere om sagen og om GIFs motiver for deltagelse i arrangementet:
»Vi er begyndt at se de første reaktioner, som tyder på, at der kan gå politik $i$ sagen. DBU vil som medlem af FIFA gøre meget for, at kampen ikke afvikles, og det kan ikke udelukkes, at der vil blive rejst en officiel forespørgsel om Grønlands holdning. Baggrunden herfor er naturligvis Kinas uvilje mod, at Tibet fremtrceder som nation. (...) Gronlands Boldspil Union er hverken forpligtet af DBU eller FIFA og kan derfor frit forholde sig til valg af modstandere. At vi har valgt at gå ind $i$ dette arrangement skyldes, at vi såvel idratsligt som politisk kunne se [det] som spcendende og interessant $\ll .{ }^{9}$

GIF var altså helt afklaret med, at afviklingen af kampen kunne medføre organisationspolitiske og udenrigspolitiske komplikationer. Det var netop disse komplikationer, der gjorde arrangementet interessant for GIF, fordi det kunne skabe røre i andedammen, tiltrække mediernes opmærksomhed og derved få sat GIFs internationale idrætspolitiske ambitioner på dagsordenen. Udenrigsdirektør Michaela Engell reagerede samme dag:

»Skфnt Udenrigskontoret hverken kan forbyde eller tillade et arrangement som det omtalte, skal man herfra opfordre til, at sagen overvejes nøje. Såfremt Grønlands Idratsforbund фnsker at gennemføre kampen, $b \phi r$ det tydeligt fremgå, at den ikke under nogen form indebarer en officiel grønlandsk anerkendelse af Tibet, men at der alene er tale om et privat arrangement. Det grønlandske samfund har store nuvarende og potentielle eksportinteresser i forhold til Kina, og dette samfunds $\phi$ konomisk vasentlige element bør ikke sattes over styr af en sportsbegivenhed. (...) Til de i skrivelsen omtalte 
overvejelser om, at arrangementet politisk set er spandend,e skal anføres, at Grønlands udenrigspolitiske relationer ressortmassigt henhører under Landsstyreformanden og ikke under Grønlands Idrcetsforbund. Vi skal derfor opfordre Gronlands Idrcetsforbund til at koncentrere sig om de eventuelle idrcetslige aspekter ved arrangementet ${ }^{10}$

Det er i denne forbindelse væsentligt for forståelsen af Udenrigskontorets position og reaktion at kaste et blik på den grønlandske eksport til Kina. Rejer var uden sammenligning den største enkeltpost med en samlet eksportværdi på ca. 620 mio. kr., hvilket udgjorde ca. 70 procent af den samlede eksportværdi for Grønland. ${ }^{11}$ Den Grønlandske Havfiskeri og Eksport Sammenslutning vurderede, at eksporten til Kina i 2000 androg en værdi på ca. 250 mio. ${ }^{12}$ Udenrigskontoret var ikke begejstret for kampen mod Tibet og GIFs politiske engagement. Udenrigsdirektøren ville have GIF til at fokusere på 'eventuelle idrætslige aspekter'. På samme tid ville Udenrigsdirektøren have GIF til 'overveje sagen nøje' og vurdere de mulige konsekvenser for den grønlandske $\varnothing$ konomi ved at deltage i arrangementet.

På den ene side beskyldte Udenrigskontoret GIF for at blande sport og politik sammen, og på den anden side opfordrede man GIF til at overveje de handelspolitiske aspekter ved kampen. Derved lagde Udenrigskontoret pres på GIF ved at pålægge GIF et medansvar for den grønlandske eksport til Kina. Jens Brinch blev bekendt med, at man i Landsstyret havde diskuteret sagen og var kommet frem til, at man ikke ville blande sig eller på nogen måde udtale sig om den. Brinch mødte også landsstyreformand Jonathan Motzfeldt, som uofficielt udtrykte sin sympati for projektet.
Dette forsikrede Brinch om, at man ikke fra Landsstyrets side havde tænkt sig at gribe ind. ${ }^{13}$

GIF og Udenrigskontoret arbejdede i virkeligheden for at opnå det samme via deres indsats på forskellige områder, nemlig at styrke den grønlandske selvstændighed. Problemet var, at GIFs valg af en kontroversiel modstander kunne betyde tilbageskridt for Udenrigskontorets arbejde med at opnå $\varnothing$ konomisk uafhængighed af Danmark, hvis kineserne skulle finde på at stoppe eller begrænse importen af grønlandske fiskeprodukter.

\section{Kineserne kommer på banen}

Den 1. maj 2001 blev Hjemmestyrets bekymringer bekræftet. En diplomat fra Den Kinesiske Ambassade mødte op i Grønlands Repræsentation i København på repræsentationschef Einar Lemches kontor med det formål at drøfte kampen. Den kvindelige diplomat gjorde opmærksom på, at den kinesiske regering så arrangementet som undergravende for den kinesiske integritet og refererede til, at Udenrigsministeriet i København havde lovet kineserne, at der ikke ville blive flaget med det tibetanske flag. Hun oplyste også, at Kina er et stort marked, og at Hjemmestyret $\mathrm{i}$ den forbindelse skulle overveje betydningen af den handelsmæssige relation til Kina, hvilket Lemche opfattede som en trussel. ${ }^{14}$ Udenrigsdirektør Michaela Engell uddyber:

"Den kinesiske ambassade i Kobenhavn henvendte sig dels til Udenrigsministeriet, dels til Gronlands Representation $i$ Kobenhavn og gjorde gaeldende, at et officielt grønlandsk samarbejde med Tibet ville blive tolket som et $\emptyset$ nske om ikke at fortsatte samarbejdet med Kina «. ${ }^{15}$ 
Således blev Udenrigsdirektøren bekræftet i bekymringerne om en skeptisk kinesisk reaktion. Ifølge kilder i Udenrigsministeriet blev ministeriet også kontaktet af kineserne, og der fandt et møde sted i mellem kinesiske diplomater og danske embedsmænd. På dette møde krævede kineserne, at ministeriet greb ind over for arrangementet, hvilket man afviste. Udenrigsministeriets strategi var at undgå, at kineserne blæste sagen op. Man forklarede kineserne, at det inden for dansk lovgivning ikke var muligt for staten at blande sig i private arrangementer, og det blev understreget, at ministeriet ikke ønskede, at det skulle udvikle sig til en »sag « mellem Kina og Danmark. ${ }^{16}$

De danske myndigheder forholdt sig generelt meget passivt og undlod at gøre andet end svare på henvendelser med det samme standardsvar: At de hverken kunne eller ville blande sig i private arrangementer. Faktisk kunne man diskutere, om de overhovedet kunne have handlet anderledes, fordi de ville have handlet direkte $\mathrm{i}$ modstrid med internationale aftaler (FN), som man $i$ alle andre sammenhænge anerkender, hvis man havde støttet kampen. Desuden ville man have trådt langt ind i en gråzone i forhold til Grundloven ved at blande sig i en privat fodboldkamp.

I forbindelse med brugen af Vanløse Idrætspark til kampen rettede regionschef $\mathrm{i}$ KI, Erik Hansen, henvendelse til Udenrigsministeriet, hvilket resulterede i følgende svar, der giver et godt billede af ministeriets position:

»(...) man betragter den forventede fodboldkamp mellem Gronland og Tibet den 30. juni i Vanløse Idrcetspark som et arrangement af privat karakter. Såfremt afviklingen af kampen $i \phi v r i g t$ er arrangeret inden for lovens rammer, er der således ikke i dansk lovgivning grundlag for officiel indblanding ${ }^{17}{ }^{17}$

Ifølge Berlingske Tidendes kilder i Udenrigsministeriet havde man forsikret de kinesiske diplomater om, at arrangørerne skulle overholde den danske flaglovgivning. Michael Nybrandt udtalte i den forbindelse, at han alligevel havde i sinde at ansøge om flagtilladelse, fordi »... det vil vare et led $i$ at gøre det til en rigtig fodboldkamp med nationalmelodier, og alt hvad der ellers hører til «. ${ }^{18}$ Der kom dog aldrig en officiel ansøgning fra arrangørernes side, muligvis fordi der aldrig herskede den store tvivl om, at en sådan tilladelse ikke vil kunne forudses givet af Justitsministeriet, da Danmark ikke anerkender Tibet som en selvstændig nation, men som en del af Kina. ${ }^{19}$ På den måde forblev udtalelsen til Berlingske Tidende en provokerende hensigtserklæring med stor nationalistisk symbolværdi.

Da det kom frem i medierne, at der var blevet lavet en aftale om leje af Vanløse Idrætspark, kunne man nogle dage senere læse i aviserne, at KI var blevet kontaktet af kineserne og inviteret til et møde på ambassaden. ${ }^{20}$ Efter invitationen fra Den Kinesiske Ambassade blev der sået tvivl om lejeaftalens gyldighed, hvilket førte til en del polemik i medierne. KI-direktør, Flemming Aanæs afviste, at henvendelsen fra ambassaden havde haft indflydelse på deres holdning i sagen. Aanæs understregede, at alle kunne spille på KIs baner, og at det kun handlede om, at lejeforholdene skulle være i orden. ${ }^{21}$ Den 15 . maj afgjorde KI, at kampen kunne spilles i Vanløse Idrætspark. Men lige som roen havde lagt sig i Danmark, kom de grønlandske arrangører i modvind. 


\section{Fiskeindustrien i Gronland}

Den 16. maj 2001 sendte Peder Munk Pedersen, formand for Den Grønlandske Havfiskeri og Eksport Sammenslutning, et brev til Jens Brinch (med kopier fremsendt til bl.a. GBU, GIF og Udenrigskontoret), hvori han understregede, at APK først og fremmest så fodboldkampen som en politisk tilkendegivelse, camoufleret bag et sportsligt ydre, og udtrykte sin frustration over kampens mulige konsekvenser for APK og Grønland. Peder Munk Pedersen underbyggede sin argumentation ved henvisning til de kinesiske henvendelser til Udenrigsministeriet og Udenrigskontoret, hvor det, ud fra hans fortolkning af situationen, var blevet gjort klart, at »fodboldkampen vil få konsekvenser for samhandlen mellem Grønland og Kina«.22 Med denne noget definitive fortolkning af de kinesiske henvendelser opfordrede APK Grønlands Idrætsforbund til at udvise omtanke i forbindelse med arrangement. Royal Greenland var i 2000 Grønlands største eksportvirksomhed og medlem af APK. Royal Greenlands andel af den samlede rejeeksport til Kina var på ca. 60 procent, og virksomheden var dermed den aktør med størst $\varnothing$ konomisk interesse i sagen.

Lars Emil Johansen, daværende vicekoncernchef og folketingsmedlem så også med stor alvor på situationen og var bekymret for eventuelle kinesiske repressalier. Johansen kunne sagtens forstå arrangørernes politiske motiver i forhold til ønsket om at træde ud af kolonimagternes (Kina og Danmark) skygge, men anså det for en meget stor eksport- og erhvervsmæssig risiko at løbe for $» 90$ minutters fornøjelse ${ }^{23}$ Han udtalte: »vi kunne ikke bare følge vores egne idealer, vi var $n \phi d t$ til at se, hvordan virkelighedens verden hanger sammen. $\ll^{24}$ Derfor anså han det for nødvendigt at præsentere GIF for den virkelige verden, dog uden at påvirke dem: »Altså ikke fordi vi politisk på nogen som helst måde фnskede at påvirke idratten på Grønland, men altså for at satte dem ind $i$ den praktiske, reelle verden ${ }^{25}$ Johansen tog kontakt til Jens Brinch, som husker: »Han advarede mig klart, han mente, det var en for stor risiko at tage«. ${ }^{26}$

APK og Johansen tog også kontakt til landsstyreformand og partifælle i Siumut, Jonathan Motzfeldt, som han informerede om sagens alvor. Motzfeldt udtrykte ifølge Johansen: »... at det eneste vi kunne gøre over for GIF, det var at gøre dem opmarksom på, at de løb de risici, der var «. ${ }^{27} \mathrm{APK}$, Royal Greenland og Lars Emil Johansen forsøgte altså via deres kontakter og netværk at oplyse om deres bekymringer i forbindelse med kampen og derved udvide GIFs beslutningsgrundlag med handelspolitiske elementer - samme strategi som Udenrigskontorets.

\section{Landsstyreformanden og Den Kinesiske Ambassade $i$ Kфbenhavn}

Den 17. maj 2001, dagen efter APKs skrivelse til GIF (som også blev sendt til Hjemmestyret), sendte landsstyreformand Jonathan Motzfeldt et personligt brev til den kinesiske ambassadør, Wang Qiliang, hvor han gav udtryk for Landsstyrets syn på sagen:

"Let me assure you that the Greenland Home Rule government has no part in this private sporting event. Within the framework of the Danish Constitution it is neither possible nor advisable for my government to intervene. We have, however, advised the Greenlandic Sporting 
Association that the scheduled event should be kept under private forms and that it should be carried out in a peaceful manner in avoidance of manifestations of any kind. The Greenland Home Rule government attaches the highest importance to a good and fruitful cooperation with The People's Republic of China, and I would like to express my sincere hope that this private event does not inflict on the mutual understanding between Greenland and China. I avail myself of this opportunity to express my higest consideration to the People's Republic of China, and I will remain «. ${ }^{28}$

At sagen overhovedet landede på landstyreformandens bord, som tilmed fandt det nødvendigt at skrive til ambassadøren, understreger sagens betydning for grønlænderne. Motzfeldt tog afstand fra arrangementet og udtrykte sine forhåbninger om, at fodboldkampen ikke ville skade samarbejdet med Kina. Motzfeldt valgte ikke at udtale sig om sagen til medierne eller i andre offentlige sammenhænge. Havde han udtalt sig offentligt, var han sandsynligvis blevet nødt til at udtrykke sin støtte til Kina og altså indirekte underkende tibetanernes position i konflikten.

Som leder af et land, der selv kæmper for at løsrive sig og komme ud af skyggen af en kolonimagt, ville det indenrigspolitisk set ikke se godt ud at støtte og anerkende en kolonimagt, der i manges øjne ansås for at være hensynsløs og undertrykkende. Landsstyreformanden stod altså i en situation, hvor han skulle holde balancen i forhold til fiskeindustrien, kineserne, idrætsverdenen og sin status som leder for et folk, der har levet i kolonimagtens skygge. Som nævnt udtrykte Motzfeldt, uofficielt, sin sympati og støtte til projektet over for Jens Brinch, og tilsvarende sine be- kymringer over for Lars Emil Johansen, og klarede sig derved gennem skærene uden at træde nogen over tæerne.

Samme dag som landsstyreformanden sendte brevet til Den Kinesiske Ambassade, havde Michael Nybrandt et møde med den kinesiske ambassadør og kulturattaché. På dette møde forsøgte Michael Nybrandt at få kineserne til at melde offentligt ud, at de ikke havde i sinde at lade fodboldkampen få konsekvenser for deres samarbejde med Grønland. Dette anså han som nødvendigt, fordi han var usikker på, om kampen overhovedet ville blive spillet, hvis ikke man kunne mane de grønlandske bekymringer i jorden. Disse bekymringer stammede fra Brinch, der havde snakket med nogle medlemmer fra GIFs forretningsudvalg, som havde været udsat for et hårdt pres fra deres bagland (fiskeindustrien), hvorfor han var bange for, at Forretningsudvalget ville beordre GBU til ikke at spille. ${ }^{29}$

Ifølge Nybrandt lykkedes det ikke at få ambassaden til at melde ud, men det blev aftalt, at Nybrandt kunne sige til pressen, at han havde været til et møde på ambassaden og fået forsikringer om, at kampens afvikling ikke ville få konsekvenser for den grønlandske eksport, hvilket han gjorde til TV2 umiddelbart efter mødet. ${ }^{30}$ En kinesisk talsmand udtalte samme dag, at det var den officielle kinesiske opfattelse, at kampen ikke længere kunne stoppes:

"Efter at Kobenhavns Idrcetsanlaeg har bestemt sig for at bakke kampen op, er der ikke mere, vi kan gøre for at stoppe den. Der har aldrig varet tale om, at Kina ville koble denne fodboldkamp sammen med spфrgsmålet om import fra Grønland - det er kun rygter $i$ pressen $«{ }^{31}$ 


\section{Mфdeaktivitet i Grønlands Idratsforbund og Gronlands Boldspil Union}

På møder den 21. og 25. maj blev fodboldkampen drøftet i GIF. Jens Brinch fortæller, at han på forhånd med stor sikkerhed vidste, hvad resultatet af afstemningen ville blive, fordi tre af fem medlemmer havde tætte jobmæssige og/eller familiære forbindelser til fiskeindustrien. Brinch lagde derfor en strategi, der gik på at få beslutningen sendt videre til GBU, fordi han var overbevist om, at GBU ville spille kampen, uanset hvad GIF anbefalede. ${ }^{32}$ I et brev til Udenrigskontoret og APK forklarede GIF resultatet af mødet:

"I disse drøftelser indgik med stor vagt de henvendelser, GIF har modtaget fra såvel Udenrigskontoret som APK. På baggrund heraf besluttede Forretningsudvalget at indstille til GBU, at kampen ikke gennemfores. Det blev meddelt $G B U$, men det blev understreget, at den endelige beslutning er $G B U s{ }^{33}{ }^{33}$

Således lykkedes det GIFs forretningsudvalg at komme frem til en løsning, hvor medlemmerne med forbindelse til fiskeindustrien undgik at træde deres forbindelser over tæerne, samtidig med at de slap for at forholde sig endeligt til, om kampen skulle spilles eller ej. De, der ville have kampen afviklet, fik ekspederet sagen videre til et mere positivt indstillet forum i GBU. Den 26. maj 2001 var der bestyrelsesmøde i GBU, hvor indstillingen fra GIF blev behandlet.

I et brev til GIF beskrev GBU, at man havde besluttet at gennemføre kampen, fordi man ikke mente, at politik og idræt hørte sammen. Desuden var der allerede blevet lagt et stort stykke arbejde i at få kampen stablet på benene. Det sidste, og tungeste, argument var, »at reprasentanter fra Kina ifølge arrangфrerne ikke har noget imod, at kampen gennemføres «. ${ }^{34}$ Således blev det besluttet at gennemføre kampen, blandt andet på grundlag af Nybrandts møde på ambassaden og ambassadens egne udmeldinger. Den 31. maj 2001 modtog Jonathan Motzfeldt et svar fra den kinesiske chargé d'affaires Wang Canfen. I brevet er det tydeligt, at kineserne have indstillet sig på, at kampen ville blive spillet:

"As you know, there is only one China in the world and Tibet is a part of it. More than 160 countries in the world including the Kingdom of Denmark recognize this principle. It is a splittist act that Dalai Lama Group should brazenly send a football team in the name of socalled »Tibetan national team « to Denmark to participate in a football match, and indulged in unbridled propaganda for this event. This has fully demonstrated their ulterior political motive to seek "Tibetan independence" with the disguise of sports, split the motherland, and thus cause troubles for Sino-Danish relations as well as Sino-Greenlandic relations. The Chinese government hopes Danish and Greenlandic sides to keep full alert on this event. I appreciate that your Home Rule Government attaches highest importance to good and fruitful cooperation with China, and I would like to express my sincere hope that Mr. Premier will take the overall situation of Sino-Danish and Sino-Greenlandic relationship into account, exert your influence, and remind the Greenlandic Sporting Association not to be used by the Dalai Lama Group, and furthermore take concrete measures to guarantee that no signs concerning »Tibet state» 
or »Tibet independence" would appear during the football match $\ll .{ }^{35}$

Kineserne anså således eksil-tibetanernes fors $\emptyset \mathrm{g}$ på at manifestere sig som en nation under dække af en sportsbegivenhed som et udtryk for splittelsespolitik. Af den kinesiske retorik følger altså, at det er tibetanernes handlinger, der skaber problemer for de dansk-kinesiske og grønlandsk-kinesiske relationer, og ikke de kinesiske reaktioner på de tibetanske manifestationer en position de blev støttet $i$ af de danske og grønlandske myndigheder. Hele sagen fik nemlig alle de involverede offentlige aktører til at bekræfte deres anerkendelse af kinesernes position i konflikten med tibetanerne.

Kineserne havde altså på dette tidspunkt accepteret, at kampen ville blive afviklet, og de havde ikke i sinde at stramme »handelsskruerne« over for Grønland. På trods af dette fortsatte fiskeindustrien sit pres på idrætsorganisationerne. I slutningen af maj/starten af juni 2001 blev der i Team Grønland afholdt et sponsormøde, hvor kampen blev diskuteret. Ifølge bestyrelsesmedlem Michael Binzer var Royal Greenlands repræsentant, Andoor Thomsen, blevet godt og grundigt præpareret af Lars Emil Johansen og APK. ${ }^{36}$ Lars Emil Johansen fortæller om sin rolle:

»Jeg ville ikke finde det morkeligt, hvis jeg havde sagt, at vi vil ikke medvirke til, at de penge vi giver, de gives til en fodboldkamp, der kan risikere at skade den grønlandske eksport. Det ville kun vare naturligt, om det var det, jeg sagde ${ }^{37}$

Baggrunden for at fodboldkampen mellem Grønland og Tibet kom op i Team Grønland-regi var et tilskud på kr. 50.000 fra Team Grønland til GBU til at afvikle en landskamp i forbindelse med forberedelserne til fodboldlandsholdets deltagelse i Island Games i juli 2001. Disse midler havde GBU, ifølge Team Grønland, påtænkt at anvende i forbindelse med fodboldkampen mod Tibet, hvorfor Royal Greenland reagerede. Efter sponsormødet havde Team Grønland et bestyrelsesmøde, som endte med en skrivelse til GBU, hvori man satte GBU ind i situationen:

»Team Grønland skal henstille, at det udbetalte tilskud ikke anvendes i forbindelse med den omtalte kamp, men at det anvendes til anden forberedelse til Island Games. (...) Royal Greenland A/S, som er en af Team Gronland's sponsorer, har gjort opmarksom på, at man på baggrund af en henvendelse fra de kinesiske til de danske myndigheder, narer en begrundet frygt for, at afviklingen af den pågaldende fodboldkamp vil indebare markbare negative konsekvenser for den grønlandske eksport af rejer til Kina. På denne baggrund har Royal Greenland A/S gjort opmarksom på, at man vil revurdere sit engagement $i$ Team Grønland og $i$ grønlandsk idrat generelt, hvis der afholdes idratsarrangementer, som indebarer negative $\phi k o-$ nomiske konsekvenser for virksomheden ${ }^{38}$

På trods af at GBU allerede havde besluttet at spille kampen, blev man underlagt et yderligere pres. $\mathrm{Nu}$ var det ikke kun den grønlandske samfundsøkonomi GBU skulle forholde sig til, men i yderste tilfælde også finansiering af grønlandsk idræt.

Kampen blev, på trods af strejke blandt flypersonale på Grønland og problemer med at få visum til en del af de tibetanske spillere, gennemført som planlagt. Der blev på trods af flagforbudet hejst et tibet- 


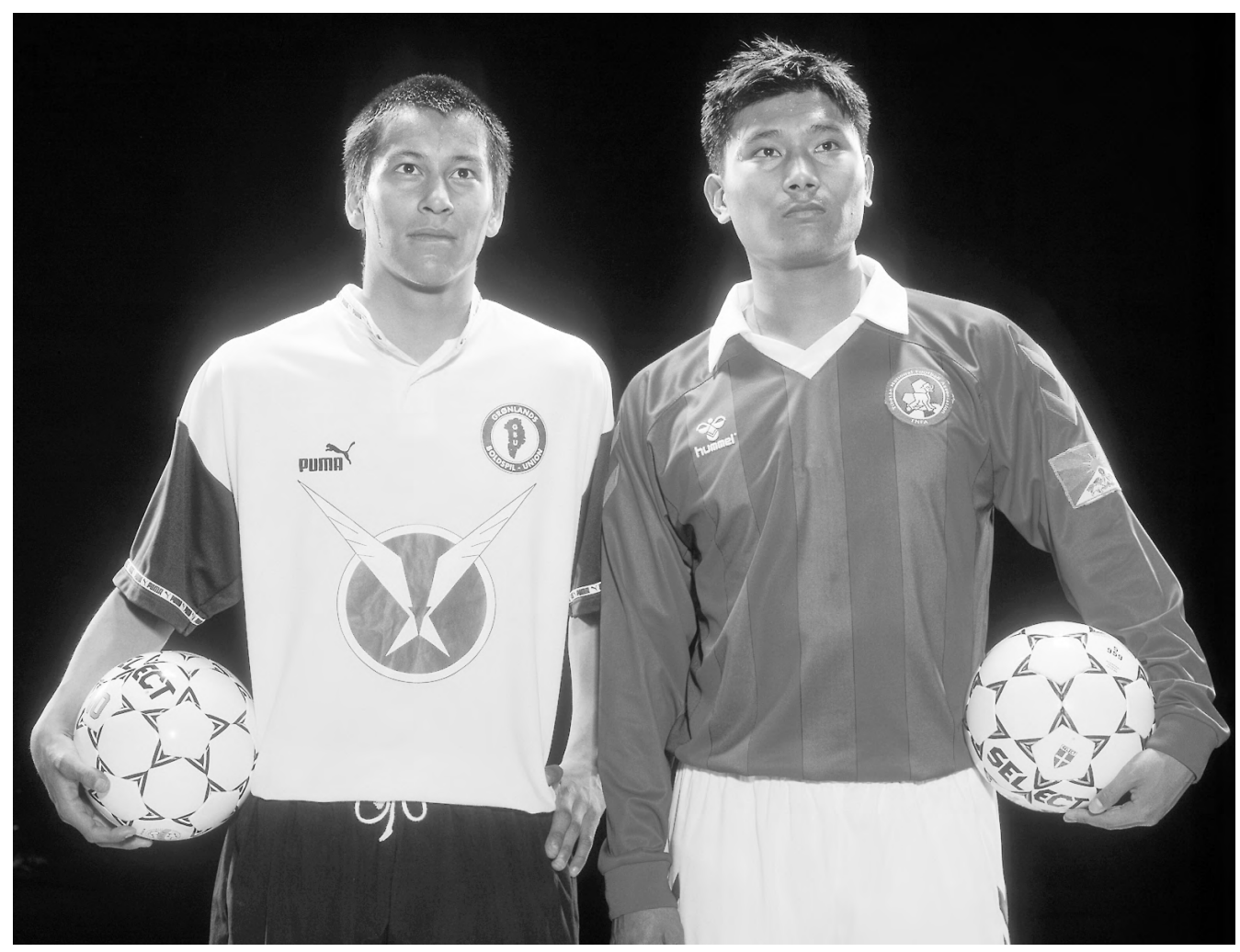

To fodboldspillere $i$ et historisk фjeblik (foto: Venligst udlånt af Michael Nybrandt).

ansk flag ved den ene indgang til Vanløse stadion side om side med et grønlandsk ${ }^{39}$, og de tibetanske farver lyste op fra mange hundrede flag og spillertrøjer fra Hummel, der blev solgt uden for Vanløse Idrætspark. Der blev sunget med på de to nationalmelodier. Fodboldmæssigt fik tibetanerne en god start og et mål efter 13 minutter. Kampen endte 4-1 til Grønland foran ca. 5.000 tilskuere og blev transmitteret på TV til mange lande. Kampen fik ikke negative konsekvenser for den grønlandske eksport. Faktisk oplevede man, at værdien af den samlede rejeeksport steg med 126 mio. kr. $(+10 \%)$, i forhold til en generel fremgang på $7 \%$ i den samlede eksport i $2002 .{ }^{40} \mathrm{Ki}$ nesernes forsøg på at stoppe den i deres øjne ulovlige kamp påvirkede ikke deres favoritstatus i forbindelse med OL 2008, som de fik tildelt i slutningen af juli 2001.

\section{Konklusion}

Når man ser på TNFAs motiver for at spille mod Grønland, tegner der sig et billede af, at det mest af alt handlede om at promovere deres sag. Fodbolden blev mere eller mindre synonym med tibetanernes selvstændighedskamp og deres bestræbelser på at opretholde en tibetansk identitet for eksil-tibetanere rundt om i verden. Det var netop sammenfletningen af disse politiske motiver og det idrætslige arrangement, der var med til at skabe den store opmærksomhed, der var omkring kampen, fordi det provokerede kineserne til at protestere. 
Selv om tibetanerne ikke fik nogen officiel opbakning og anerkendelse, fik TNFA, ved at spille sin første internationale fodboldkamp med et officielt præg, markeret sig som organisation, og gav derved tibetanerne en oplevelse, der potentielt kunne give dem en følelse af fællesskab.

Der var mange ligheder mellem TNFAs og GBUs bevæggrunde for at spille kampen. GBU/GIF var interesseret i at få sat fokus på ønsket om uafhængigheden af Danmark i international idræt. Engagementet i kampen bragte GBU og GIF på kollisionskurs med Udenrigskontoret og fiskeindustrien, der på en anden front forsøgte at bringe Grønland ud af sit økonomiske afhængighedsforhold til den gamle kolonimagt - Danmark. Problemet var, at GBUs valg af Tibet som modstander havde potentiale til at forstyrre Udenrigskontorets arbejde og ødelægge APKs medlemmers markeder. Derfor mente Udenrigskontoret og APK, at GIF og GBU skulle tage den grønlandske rejeeksport med i deres overvejelser om, hvorvidt man ønskede at spille kampen. På den måde blev der lagt pres på de grønlandske idrætsorganisationer for at få dem til at aflyse kampen ved at få dem til at føle sig ansvarlige for eventuelle negative konsekvenser for eksporten.

De grønlandske politikere og embedsmænd stod i et dilemma. På den ene side sympatiserede de med tibetanernes $\varnothing$ nske om selvstændighed, og på den anden side stod de med et $\varnothing$ konomisk ansvar over for den grønlandske befolkning, hvilket bl.a. udmøntede sig i udenrigsdirektørens position i forhold til GIF. De stod i en situation, hvor den mest pragmatiske løsning var at kalde det et »privat arrangement « og hen- vise til FN, hvormed man undgik, at det udviklede sig til en storpolitisk konflikt mellem Grønland/Danmark og Kina. Prisen for denne konfliktskyhed var imidlertid en »tavs « officiel anerkendelse af den kinesiske position i Kina-Tibet konflikten. Denne tavse anerkendelse ville, set ud fra et indenrigspolitisk synspunkt, ikke være populær ellers stemmeslugende. Derfor blev der trådt meget forsigtigt, og der var ingen danske eller grønlandske regeringspolitikere, der udtalte sig om sagen offentligt. APK og Royal Greenland var mere »frie« end de offentlige myndigheder i Grønland i forhold til at sætte deres indflydelse direkte igennem, hvilket de gjorde på flere fronter.

Der blev lagt pres på GIF og GBU, hvilket førte til, at GIF, med direkte henvisning til eksporten til Kina, indstillede til GBU, at kampen ikke blev gennemført. Royal Greenland truede Team Grønland med at trække sig som sponsor, hvis Team Grønland medvirkede til arrangementer, der kunne have skadelige konsekvenser for deres eksport. Kineserne ville formentlig gerne have været foruden kampen, men samtidig fik de Udenrigsministeriet, Justitsministeriet, Hjemmestyret, DBU og KI til at anerkende og understrege, at Tibet er en del af Kina. Landsstyreformandens brev til den kinesiske ambassadør var et godt eksempel på en sådan indrømmelse. Formandens svar til Qiliang efterlod ingen tvivl om Kinas overlegne position i forhold til Grønland og en presset landsstyreformand. Således endte fodboldkampen med at blive et vigtigt og interessant eksempel på, hvordan sport og politik kan være to sider af samme sag. 


\section{Noter}

1. Udenrigsministeriet til , 26/03/2004.

2. Politiken, 01/03/2000.

3. Michael Nybrandt, 17/05/2004.

4. Nybrandt i Jyllands-Posten, 15/10/2000.

5. Nybrandt, 17/05/2004.

6. Jens Brinch, 21/05/2004.

7. Jens Brinch i Politiken, 04/05/2001.

8. Jens Brinch, 21/05/2004.

9. Grønlands Idrætsforbund til Udenrigskontoret, 03/04/2001.

10. Udenrigskontoret til Grønlands Idrætsforbund, 03/04/2001.

11. Nyhedsbrev nr. 13, Økonomidirektoratet, december 2000.

12. APK til Grønlands Idrætsforbund, 16/05/2001.

13. Jens Brinch, 21/05/2004.

14. Einar Lemche, 04/05/2004.

15. Michaela Engell, 06/04/2004.

16. Udenrigsministeriet, 22/04/2004.

17. Udenrigsministeriet til Købnehavns Idrætsanlæg, 07/05/2001.

18. Michael Nybrandt i Berlingske Tidende, 02/05/ 2001.

19. UM til KI, 07/05/2001.

\section{Kilder}

\section{Dokumenter}

Udenrigskontoret til Grønlands Idrætsforbund, 03/04/ 2001

Grønlands Idrætsforbund til Udenrigskontoret, 03/04/ 2001

Udenrigsministeriet til Justitsministeriet, 05/07/2001

Udenrigsministeriet til Københavns Idrætsanlæg, 07/ 05/2001

APK til Grønlands Idrætsforbund, 16/05/2001

Landsstyreformanden til Den Kinesiske Ambassadør, $17 / 05 / 2001$

Grønlands Boldspil Union til Grønlands Idrætsforbund, 26/05/2001

Grønlands Idrætsforbund til APK og Udenrigskontoret, 28/05/2001

Den Kinesiske Ambassade til Landsstyreformanden, 31/05/2001

Team Grønland til Grønlands Boldspil Union, 07/06/2001

Udenrigsministeriet til , 26/03/2004
20. Berlingske Tidende, 11/05/2001.

21. Berlingske Tidende, 11/05/2001.

22. APK til Grønlands Idrætsforbund, 16/05/2001.

23. Lars-Emil Johansen, 27/04/2004.

24. Lars-Emil Johansen, 27/04/2004.

25. Lars-Emil Johansen, 27/04/2004.

26. Jens Brinch, 19/03/2004.

27. Lars-Emil Johansen, 27/04/2004.

28. Motzfeldt til Qiliang, 17/05/2001.

29. Jens Brinch, 21/05/2004.

30. Michael Nybrandt, 12/03/2004.

31. Berlingske Tidende, 18/05/2005.

32. Jens Brinch, 19/03/2004.

33. Grønlands Idrætsforbund til APK, 29/05/2001.

34. Grønlands Boldspil Union til Grønlands Idrætsforbund, 26/05/2001.

35. Wang Canfen til Jonathan Motzfeldt, 31/05/2001.

36. Michael Binzer, 05/04/2004.

37. Lars-Emil Johansen, 27/04/2004.

38. Team Grønland til Grønlands Boldspil Union, 07/06/2001.

39. Politiken, 01/07/2001.

40. Grønlands udenrigshandel 2002, Grønlands Statistik.

Personlige interviews og korrespondancer

Binzer, Michael: 28/03/2004, 05/04/2004, 09/04/ 2004 og 11/05/2004

Brinch, Jens: 19/03/2004 og 21/05/2004

Engell, Michaela: 06/04/2004

Johansen, Lars Emil: 27/04/2004

Lemche, Einar: 04/05/2004

Nybrandt, Michael: 12/03/2004 og 17/05/2004

Udenrigsministeriet, 22/04/2004

\section{Avisartikler}

Politiken: 01/03/2000, 17/04/2000, 17/04/2000, 01/ 06/2000, 02/12/2000, 01/05/2001, 04/05/2001, $11 /$ 05/2001, 17/05/2001, 21/05/2001, 18/06/2001, 20/ 06/2001, 29/06/2001, 30/06/2001, 01/07/2001.

Berlingske Tidende: 01/05/2001, 02/05/2001, 11/05/ 2001, 17/05/2001, 18/05/2001, 19/06/2001, 21/06/ 2001, 24/06/2001, 27/06/2001, 28/06/2001, 30/06/ 2001, 01/07/2001. 
Jyllands-Posten: 15/10/2000, 02/12/2000, 01/05/ 2001, 02/05/2001, 16/05/2001, 18/05/2001, 10/06/ 2001, 30/06/2001, 01/07/2001, 04/07/2001

Ekstra Bladet: 15/12/2000, 01/05/2001, 16/05/2001, 26/06/2001, 29/06/2001 og 01/07/2001

B.T.: $01 / 05 / 2001,02 / 05 / 2001,16 / 05 / 2001 ， 28 / 06 /$ 2001, 30/06/2001 og 01/07/2001

Flensborg Avis: 02/05/2001, 02/07/2001

Fredericia Dagblad: 16/05/2001

Information: 28/06/2001
Diverse artikler og publikationer

Grønlands Statistik: Grønlands udenrigshandel 2002

Økonomidirektoratet: Nyhedsbrev $n r$. 13, december 2000

Landsstyrformanden: Udenrigspolitisk Redegфrelse 2000 
